\title{
Character Education and the Disappearance of the Political
}

\author{
Judith Suissa, Institute of Education, London
}

\section{Introduction}

Character education, for many years a deeply unfashionable idea due to its "historical associations with various forms of religious and moral indoctrination of the young" (Grace, in Arthur, 2003, p.x), is definitely back on the agenda in English education policy. There has, for some years, been policy interest in and support for a range of initiatives that promote a form of character education in schools.

Many such initiatives have been subject to criticisms from theorists and practitioners concerned with issues of social justice, who express worries about the political assumptions behind them, either in the sense that they are seen as inherently right-wing or conservative, or that they are, as part of the "therapeutic turn", recasting social problems as individual problems.

While I have some sympathy for these criticisms, my focus in the following discussion is not on the alleged, explicit or assumed ideological assumptions behind current character education programmes, but on the way in which they displace the idea of political education and, through their language and approaches, avoid any genuine engagement with the very concept of the political in all but its most superficial sense. In exploring some of the points raised by critics of character education, I defend the need for a more robust and radical conception of the political as a basis for a form of political education.

Kathryn Ecclestone, one of the most prolific and rigorous critics of recent versions of character education, points out (Ecclestone, 2012) that this new trend is broad enough to encompass theorists of different political persuasions. It can no longer simply be written off as a project of the conservative right or the religious lobby, and has attracted supporters from across the political spectrum, as reflected in the following statement from the thinktank Demos, whose influential Character Inquiry was published in June 2011: "There is growing interest in the political and policy importance of a certain set of personal attributes 
- in particular emotional control, empathy, application to task, personal agency, an ability to defer gratification - that might be summarized as 'character'. [...] While the terminology differs - in different cases, terms such as emotional resilience, social and emotional skills, or life skills, might be used - the central, and perhaps growing, importance of character is being recognized across intellectual disciplines and across the political spectrum." (http://www.demos.co.uk/projects/the-character-inquiry)

Similarly, Learning for Life, an umbrella organization that coordinates the work of a number of bodies developing character education projects in the UK, in expressing a concern that too much emphasis in the education system has been placed on competitiveness and future employment prospects, states: "A reinvigorated conscious focus upon character education in schools is a necessity, if a proper balance is to be restored to the educational process." (http://www.learningforlife.org.uk/about/frequently-asked-questions/)

\section{Criticisms of Character Education}

In spite of their allegedly broad appeal, many recent initiatives in the field of character education have been the target of rigorous criticisms from philosophers and others. I now turn to a discussion of some of these criticisms in order to address the important conceptual and political issues that they raise.

Dwight Boyd, writing in a North American context, has criticised an approach to character education that he claims "has now achieved the status of a movement in the U.S." (Boyd, 2011, p. 147), arguing that "there is a highly conservative nature to almost all contemporary character education discourse" (ibid). The programmes he has in mind, which draw on the work of Thomas Lickona, one of the most influential theorists in the field, are those that defend a list of "essential virtues". Boyd refers to the "epistemological arrogance" (ibid, p. 150) typical of these programmes, which strive at consensus over items on such a list, thereby ruling out disagreement and, in doing so, promoting a kind of "willful difference blindness" (ibid, p. 152) that ends up propping up the status quo. A central flaw in such approaches, Boyd argues, is their conceptual confusion between "the good" and "the right". Boyd notes that "it is the contrast between the work done by 'the good' versus 'the right' 
that is so critical to liberal political theory, particularly in its aim of addressing the inevitability of difference and conflict among citizens" (ibid). In failing to acknowledge this distinction, and consequently blurring the distinction between the good person and the good citizen, such character education programmes end up being "discursively productive of a very conservative political perspective that serves to protect the status quo of social relations-[...], ignoring or hiding difference or conflict." (ibid, p. 162). Thus "by ignoring these deeper, more insidious social conditions [of systematic oppression faced by women, members of the working class, or those in racialized and sexually marginalized groups] this movement becomes politically conservative by default, if not by design" (ibid, p. 148).

Boyd's solution is to offer a more "left field" approach to character education which assumes the Rawlsian distinction between the right and the good and focuses on the central political virtue of justice, adding the important perspective offered by Iris MarionYoung's work on the oppressive relations between relationally defined groups in order to articulate specific virtues required to address the oppression of racialized and other marginalized groups.

I find Boyd's analysis persuasive and am sympathetic to his argument that in a society such as the US, where issues of oppression on the basis of class, race and gender are so deeprooted and pervasive, educational interventions concerned with democratic citizenship need to have a far more rigorous and central concern with issues of justice, and a social ontology more akin to that of Young than to that of Rawls. Yet at the same time, I am concerned that the conceptual distinction between the right and the good that Boyd regards as so indispensable to a robust approach to character education, glosses over some of the political tensions within the liberal project itself.

Projects for character education in English schools, such as those developed and supported by the Jubilee Centre for Character and Values founded at the University of Birmingham in 2012, may seem on the face of it less politically worrying than the US programmes that Boyd discusses. While the Jubilee Centre website also makes prominent reference to the work of Thomas Lickona, many of the educational programmes developed and promoted by the Centre are explicitly concerned with the virtue of justice (see http://jubileecentre.ac.uk/userfiles/jubileecentre/pdf/other-centre-papers/Framework). 
However, statements such as the following, from the Centre's "Framework for Character Education in Schools" - "Schools do and should aid students in knowing the good, loving the good and doing the good. Schools should enable students to become good persons and citizens, able to lead good lives, as well as 'successful' persons," suggest that there may be a similar conflation here to that which concerns Boyd, overlooking the central tenet of liberal theory that "the 'good citizen' is a distinct role, not to be confused with the more general one of 'the good person'" (Boyd, 2011, p. 154).

In fact, as I discuss below, the conceptual distinction that Boyd defends opens up more tensions and questions than it resolves. The way to address these tensions, however, is, I suggest, not by a theoretical debate conducted within the academic discourse of political philosophy, but by bringing them into the classroom. Without a more radical conception of just what "the political" means, and without engaging children in debates about how political aims, ideas and values are intertwined with, yet importantly distinct from, moral values, there is no hope of engaging children in the pursuit of a more socially just and less oppressive society.

The problem identified by Boyd in his criticism of character education programmes is very different from that identified by critics such as Kathryn Ecclestone, who argues that "discourses of well-being and character both recast virtues and moral values as psychological constructs that can be trained without requiring moral engagement." (Ecclestone, 2012, p. 476).

Yet both critics are concerned with the wider political issues behind problems that advocates of character education often claim to be addressing. As Ecclestone argues, contemporary initiatives in the field of character education are explicitly linked to the positive psychology movement and its focus on boosting and measuring subjective wellbeing. For example, the recent "Positive Education Summit" held at Wellington College in 2013 and co-sponsored by the Jubilee Centre, was aimed at "highlighting the benefits of placing character and wellbeing on the timetable." Reflecting the general tenor of such projects, the statement issued by the organizers of the summit, who included Martin Seligman, the guru of positive psychology, and James O'Shaughnessy, a former adviser to David Cameron and one of the engineers of the UK government's recent "happiness index", 
announced "We are calling on all schools to embrace positive education and introduce explicit character education into the curriculum." (see http://lightsandcolors.com/pes/thesummit/)

Analysing this discourse, Ecclestone explains that "emotional and psychological well-being" is an umbrella term that

\footnotetext{
"draws in an extensive set of 'constructs' seen as amenable to development. These include resilience, stoicism, an optimistic outlook, an ability to be in the moment (or 'in flow'), feelings of satisfaction, being supported, loved, respected, skills of emotional regulation, emotional literacy (or emotional intelligence) as well as empathy, equanimity, compassion, caring for others and not comparing yourself to others" (Ecclestone, 2012, p. 464).
}

She argues that "the revival of an old discourse of 'character' incorporates concerns with morals and virtues within a psychological depiction that embraces all the constructs of wellbeing within a more inclusive set of 'capabilities', and hopes to find ways to measure them."

Ecclestone is careful to point out that "Unlike earlier discourses of emotional and psychological well-being, the new discourse appears to encourage moral and political questions" (ibid, p. 270), and includes advocates with liberal-Left and communitarian sympathies. Nevertheless, the overwhelming therapeutic tenor of most educational interventions premised on such approaches inevitably, according to Ecclestone, "psychologises moral dimensions to well-being and character in a social project that aims to engineer them through state-sponsored behaviour training," (ibid, p. 465), encouraging a diminished view of the subject positioned as in need of such interventions. Ecclestone argues, powerfully, that

"We need a political and educational challenge to a social project that hopes to engineer emotional and psychological well-being and character whilst avoiding civic engagement in the political questions this raises. The problem is that if the human targets of therapeutically informed behavioural interventions accept 
their underlying emotional determinism, they are in no fit state to engage in these questions." (ibid, p. 477).

My concern is that there is no clear conception, either within the theoretical literature or within current educational policy, of just what a "political question" is, or what the very realm of "the political" consists in and what it means to think about political questions and moral questions. My suggestion is that, as with the challenges raised by the conceptual distinction between "the good" and "the right", we try to bring such questions and challenges into the heart of educational practice. How can children be expected to play a part in political life if they don't undertand what "political" means, or what kinds of questions can be described as "political"?

\section{The political and the moral}

Boyd, in defending a "left field" approach to character education, cites the work of Ben Spieker and Jan Steutel, which draws on Joseph Raz's notion of the capacity for a sense of justice, in support of his argument that "critical, reasonable engagement of difference and conflict" is an essential component of character education in a pluralistic liberal democracy. Spieker and Steutel argue that the virtue of justice, on the Rawlsian conception, is a distinctly political virtue and as such, "although there may be overlap with the character traits of a moral person in general", they are different as they do not depend on any "grounding in a particular comprehensive doctrine" (Boyd, 2011, p. 157). Yet Boyd's discussion here glosses over the contested nature of these very distinctions, which have been the subject of a great deal of debate within political philosophy. Bernard Williams, for example (Williams, 2008), has defended what he calls a "realist" conception of political philosophy against the Rawlsian normative, "moralist" conception, arguing that Rawls' conception of justice is itself moral. Similarly, Susan Mendus, discussing the related distinction between "the right" and "the good", points out that "it seems optimistic to suppose, as Rawls must, that different conceptions of the good will not spill over into (or even arise from) different conceptions of the right" (Mendus, 2006, p. 236). Disagreements 
in politics are, she says, "not simply disagreements about the highest ideals but also about what justice consists in and requires" (ibid).

This central debate in political philosophy is often framed as a conflict between two competing answers to the question "What is political philosophy?", which are seen as reflecting two philosophical traditions, one of which considers political philosophy to be a special branch of the more general area of moral philosophy, while the other sees it as an autonomous discipline (see Larmore, 2013). This conflict is echoed, yet not addressed, in a great deal of the character education literature, which either seems to assume one or other of the two opposing positions in the debate, or to simply elide the two.

Many proponents of contemporary character education initiatives in Britain draw explicit links with citizenship education, as in James Arthur's claim that "character education can be understood to be a specific approach to moral or values education and is consistently linked to citizenship education" (Arthur, 2005, p. 239), and such calls often invoke the notion of "civic virtues". Yet not all arguments for an education in civic virtues can be interpreted as belonging to a republican or Aristotelian tradition - the tradition most closely associated with the view that "political philosophy must proceed within the framework of the larger enterprise of moral philosophy" (Larmore, 2012, p.9), nor do they necessarily accept the Aristotelian idea of the political life as the "highest, most comprehensive form of human association since its principal aim is to promote the ultimate end of all our endeavours, the human good itelf" (ibid, p. 8). In fact, as Eamonn Callan noted some time ago, "An antipathy to talk of civic virtue runs deep in the liberal political tradition" (Callan, 1998, p. 211). Liberal theorists, Callan explains, have often been suspicious of "virtue-based politics" due to the worry that it will impose "an illiberal character standardization on citizens" (ibid), thus undermining "the dissent and individuality that a free society will properly welcome" (ibid). Yet Callan himself, along with several other theorists, has defended the idea that "for people whose fundamental political orientation is democratic - including those who are quick to add that the only democracy worth having is liberal - a wholesale renunciation of civic virtue cannot possibly be appealing" (ibid). Callan, along with other theorists such as Patricia White (see White, 1998, 1983), has argued that civic virtues are necessary in a democracy, and has developed an account of liberalism as "a politics of virtue" depending 
on the understanding that "justice as reasonableness" is necessary for free and equal citizens (ibid). Likewise, Kymlicka (2001, p. 294) claims that "the health and stability of a modern democracy depends, not only on the justice of its 'basic structure,' but also on the qualities and attitudes of its citizens".

One does not have to be a republican or a communitarian to accept, with Patricia White, (1980, p. 149) that "democratic politics is a moral matter", and that it therefore makes little sense to have "a privatized moral education, on the one hand, [...] and on the other a political education concerned only with a descriptive element of the society's political institutions" (ibid). Yet to argue for a conceptual and practical connection between moral education and political education is not to endorse the kind of psychologically-oriented forms of character education typical of recent initiatives that elide citizenship education and character education. Nor should the acknowledgement that moral and political philosophy both "have to do with the principles by which we should live together in society" (Larmore, 2013, p. 1), and that therefore, as White points out, moral considerations play a role in political argument, lead us to overlook the importance of the distinction between political questions and purely moral questions.

Yet what is remarkable in current calls for a form of character education seen as part and parcel of citizenship education is not just their confusion over these basic issues to do with how to conceptualize political theory, political education, and their correspondoing relationship to moral theory, but their complete expunging of the language of politics from their rhetoric. The notion of "the political" has, it seems, been displaced by this emphasis on "citizenship" and "character". The word "political" rarely appears in the various statements and proposals issued by the Jubilee Centre, and when it is used in work by academics writing on citizenship and character education (see e.g. Arthur, 2003; Althof and Berkowitz, 2006), it is generally done so in the context of "political participation", as if what is important is that children be prepared for participating in something already defined as the political system; not that they engage in meaningful thought and discussion about just what such a system is, what it should be, what participation in it consists in or why it may be valuable. 
We need, I argue, to bring back a focus on the political, and an attempt to get children to see political thinking, argument and action as a particular form of human engagement concerned with particular kinds of questions. Charles Larmore (2013), attempting to move beyond the opposition between the so-called "realist view" associated primarily with Bernard Williams and Raymond Geuss and the "moralist" view associated primarily with G.A. Cohen, defends a view of political philosophy as concerned with "the problem of how people like us are to live together". What I want to suggest is that for educational interventions in this area to have any real political significance, what is important is not that proponents of various approaches to character education resolve their philosophical disagreements, get clear on the distinction between the good and the right, or identify themselves as Aristotelians or Liberals. What is essential is that the political - understood as that whole realm of human enquiry and experience that touches on the question of "how people like us are to live together" - is brought back into the classroom as a live issue.

For children in schools to develop any genuine understanding of the meaning of the political, they need to understand not only how moral questions can be conceptually distinguished from political questions, but how they interact. This may seem paradoxical, but Larmore explains the point well when he argues that "the characteristic problems of political life include widespread disagreement about morality", and are as such a distinct realm from moral philosophy, "yet it cannot determine how these problems are to be addressed except by reference to moral principles understood as having an antecedent validity." (Larmore, 2013, p.5) .

I suggest, then, that children need to be given opportunities to think about what "the political" means, and that in providing such opportunities, educators need to be prepared to embrace the complexity suggested by the above discussion. Yet acknowledging this complexity and adopting a perspective like Larmore's is not sufficient for this task, for Larmore is afflicted with the "state fixation" (Miltrany, 1975, p. 98) typical of many liberal theorists, and thus his perspective is narrowly focused on the existing framework of liberal democracy. I explore this issue in detail below. 


\section{The absence of the political in character education}

One way in which the political is written out of character education programmes is, as Ecclestone notes, in their failure to address the moral and political context of notions such as courage and resilience that are a central feature of many such programmes. To illustrate this point, I turn to an examination of the notion of resilience. As Ecclestone explains,

Influenced strongly by positive psychology and cognitive behavioural therapy (CBT), resilience is one of several, inter-related constructs that comprise 'emotional well-being' [...] In interventions based on this understanding, resilience is a foundation for a broader set of desirable social and emotional competences. More recently, it has become a key construct in a politically endorsed revival of an old discourse around 'character building' (Ecclestone, 2014, p. 196)

Yes while Ecclestone is keen to show how the notion of resilience in such interventions is premised on a narrow psychological-behaviourist approach, and to promote a more critical perspective, what I want to argue here is that the space in the curriculum allocated to such programmes of personal and citizenship education can perhaps offer opportunities for directly engaging in discussion of "the political" as described above, and thus bringing back a more meaningful form of political education. One way into this, for example, is to ask students: Are there things we shouldn't be resilient to?

The UK Resilience Programme, a version of the Penn Resiliency Program developed by Martin Seligman, was piloted in 22 schools in England in 2007 and has since been taken up by dozens of schools (see http://www.howtothrive.org/thrivingschools/penn-resilienceprogram). The Thinking Minds website, one of the key resources for the programme, states: "Put simply, resiliency refers to the capacity of human beings to survive and thrive in the face of adversity."

While I share Ecclestone's worry about the way such ideas are framed as "psychological constructs that can be trained without requiring moral engagement" (Ecclestone, 2012, p. 
476), my suggestion is that we take such "moral engagement" into the school itself, and try to engage children in a real understanding of the political realm and political discussion as involving basic moral questions - questions, for example, about human needs and the social obligations related to these needs. As a way into this endeavour, the question "Are there some things we shouldn't be resilient to?" has clear echoes of Martin Luther King's idea of "creative maladjustment". In his 1967 speech to the American Psychological Association, King said:

There are certain technical words within every academic discipline that soon become stereotypes and cliches. Modern psychology has a word that is probably used more than any other word in modern psychology. It is the word 'maladjusted.' This word is the ringing cry to modern child psychology. Certainly, we all want to avoid the maladjusted life. In order to have real adjustment within our personalities, we all want the well-adjusted life in order to avoid neurosis, schizophrenic personalities. But I say to you, my friends, as I move to my conclusion, there are certain things in our nation and in the world which I am proud to be maladjusted and which I hope all men of good-will will be maladjusted until the good societies realize. I say very honestly that I never intend to become adjusted to segregation and discrimination. I never intend to become adjusted to religious bigotry. I never intend to adjust myself to economic conditions that will take necessities from the many to give luxuries to the few. I never intend to adjust myself to the madness of militarism, to self-defeating effects of physical violence.

As an aside, I think that the fact that Martin Seligman's Penn Resilience Training Program is now offering resilience training to soldiers in the US army at a cost of \$125 million is enough to prompt the question whether there are some things we don't want people to be resilient to. My general point, though, is that asking children to reflect on this question seems like a good way to prompt them to engage in genuine political discussion, and to go on to think about what this question implies, both in relation to their own experience and in relation to wider normative moral questions about how society should be organized. However, this 
kind of questioning can only carry a powerful moral and political impetus if our political systems and institutions are from the outset conceived as essentially malleable.

Thus my call for the political to be brought back into moral and citizenship education is not a call to reintroduce the kind of "political literacy" advocated by Bernard Crick, who argued, in his call for political education in schools, that "a person who has a fair knowledge of what are the issues of contemporary politics, is equipped to be of some influence, whether in school, factory, voluntary body or party, and can understand and respect, while not sharing, the values of others, can reasonably be called 'politically literate'". (Crick and Porter, 1978, p. 7).

There have in fact been some recent calls in the UK for a revival of this kind of political literacy. For example, in April 2011 The Independent reported that the President of the National Association of Schoolmasters had told their annual conference that "Youngsters should receive compulsory lessons in political education before they leave school", as it would "give them a grounding in democracy and encourage more to vote in later life", going on to claim that "An impartial education in politics would increase participation in elections with electors voting armed with a knowledge and understanding of party politics rather than a reliance on spin and media prejudices," (Independent, 2011). Likewise, Harrison Jones (2013) complains: "Why is it compulsory to learn about shape theorems, textiles and gymnastics, but not the political system under which we live? Secondary school pupils leave education without formal teaching in such basic things as how the British political system operates, an overview of mainstream ideologies - alongside their (apparently) corresponding UK parties, and the mechanics of different voting systems."

Such calls for political education in schools refer to voter apathy and low turn-out at elections. But what they have in common with contemporary character education programmes is that they see the political system as simply that - the system which we have. A similar perspective is implicit in the principles of effective citizenship education set out by the Advisory Group on Education for Citizenship and the Teaching of Democracy in Schools, namely that "citizenship should develop social and moral responsibility, community involvement and political literacy." (Crick, 1998) 
Quotes such as the above give the impression that the problem is children's lack of factual knowledge of central aspects of the existing political system. Yet this begs the question of whether children even know what "political"means. My suggestion is that this is the more urgent educational task, and that if it is to be undertaken in a way which will encourage children to engage with political ideas, debates and processes, it must embrace both the idea of political questions as being basic normative questions about, as Larmore says, "how to live together in society", and an understanding of political arrangements as essentially malleable. This requires far more than an idea of political literacy and a grasp of the institutions and mechanisms of democracy.

Patricia White, like some other earlier advocates of political education (see e.g. Wringe, 1984), is careful to point out that educating children for the kind of democratic dispositions she defends does not imply being "blindly committed to the arrangements of any particular democratic state" (White, 1980, p. 149). Yet this view seems somewhat lacking from current character education programmes - perhaps unsurprisingly in a climate in which mainstream political debate is dominated by the discourse of no alternative.

Adopting a more robust conception of the political as a basis for political education requires that educators concerned with social justice be willing to entertain the idea that a reality characterized by radical problems of poverty, growing inequality and impending ecological disaster may require radical political solutions. Central to this approach is a view of our political structures as malleable and of politics as an ongoing process of engagement with moral questions, rooted in human experience, as to how to shape and organize society. The absence of such a perspective from contemporary character education programmes is evident not just in the way in which citizenship is framed, as discussed above, but also in the way in which political issues are discussed within curricular resources on specific virtues. For example, the Jubilee Centre project, "Knightly Virtues", which has been run in 65 primary schools across Britain, involving over 3250 students (see http://www.jubileecentre.ac.uk/417/projects/development-projects/knightlyvirtues\#sthash.EFOvivAe.dpuf.), includes a supplementary pack on the story of Rosa Parks, designed "to explore in greater depth the virtues of courage and justice." ii 
The emphasis on the personal character of Rosa Parks in the presentation of and questions about her story suggests a view of the political as something out there and given, with the important questions being questions for the individual: "What do you think were the different virtues displayed by Rosa Parks?" "What do you think you might have done if you had been on the bus?" The image of Rosa Parks as an individual with particular character traits, acting on her own, is in fact reinforced by many standard narratives about her, which ignore the well-documented fact of her involvement with the influential Highlander Center, that provided education and leadership training for civil rights activists. As Morris (1984) comments, the educational activities that Rosa Parks participated in at the Highlander Center were part of a process that theorists of collective action and political movements define as "cognitive liberation" (see McAdam, 1999). Although Parks' involvement with the Centre and with the Association for the Advancement of Colored People is mentioned in the Jubilee Centre material, the focus on the question of her individual character, and the very framing of the question "Can an individual change society?" shifts the emphasis away from these kinds of collective political movements and the hope and belief they embody that the political system can be radically changed.

This narrow view of the political in which it is implied that radical social change is less feasible than the cultivation of personal character strengths is supported in the work of academics involved in the Jubilee Centre, such as Kristján Kristjánsson, who has responded to the objection often raised that character and virtue education are individualistic notions. These criticisms, he argues, generally have as their target "US-style character education of the 1990's and current positive psychological virtue theory" (Kristjánsson, 2013, p. 279). While acknowledging the primacy of "inward gaze and personal achievement" in such programmes, their position, Kristjánsson argues, is that

the question of individual versus societal reform is a chicken-and-egg one - we need to start somewhere and, for developmental and pragmatic reasons, it is more feasible to start with the individual child, student or classroom than the whole school system of society at large (ibid) . 
This argument seems to me at best naive and at worst disingenuous. Firstly, as even a cursory understanding of Marx's theses on Feurebach indicates, the "pragmatic" solution proposed here by no means escapes the complex social and political questions raised by this issue. Crucially for educators, if one genuinely believes that radical social change is necessary to overcome urgent social problems of injustice, inequality and oppression, then surely an essential part of such an approach is convincing people that such change is both possible and necessary, and creating a climate of public political discourse where ideas about what and how to change, and why, are openly debated and argued for. An educational approach that puts all pedagogical emphasis on individuals and their character traits mitigates against this, both reflecting and reinforcing the dominant policy discourse that views the system as here to stay and individuals as to blame for social problems.

\section{The Political Imagination}

Taking the educational stance that "the political" is a central and distinct form of human engagement, bound up with moral questions about how we are to live together, and that any political system is inherently malleable and subject to change through collective action, will perhaps do something to discourage the kind of apathy remarked on by commentators. The approach to political education that I am defending here requires a flexibility and openness on the part of educators, that acknowledges that the question of what form our society should take is not fully decided, that the kinds of crisis facing us today demand radical solutions, and that perhaps a way to encourage the articulation of and participation in such solutions is to foster imaginative political thinking about the kind of society we want.

In the context of calls for civic education, Dewey is often cited as a democratic thinker we need to heed more. John Covaleskie, for example, in calling for "a deliberate and deliberative effort to foster the virtues of character and intellect that democracy requires of its citizens " (Covaleskie, 2011, p. 168), argues that we need to take seriously the obligations implied in the idea of a public developed in Dewey's work. But what is often overlooked by such advocates of democratic civic virtues is that an important element of Deweyan Pragmatism is, as commentators like Paul Goodman and Richard Rorty have noted, its 
utopian aspect (see Rorty, 1999). As Goodman remarks, "in a climate where experts plan in terms of an unchangeable structure, a pragmatic expediency that still wants to take the social structure as plastic and changeable comes to be thought of as 'utopian'" (Goodman, 1952, pp 18-19).

At first glance, one of the "Big Questions" posed on the Jubilee Centre's website: "How does the power of good character transform and shape the future of society?" certainly suggests that proponents of this approach are hardly concerned with simply preserving the political staus quo. Yet, as discussed above, the assumption here is that individuals can learn, through appropriate pedagogical interventions, something called "good character", and that this in turn can lead to social improvement. What is lacking, I have argued, is an educational engagement in the moral and political questions about just what such improvement consists in, and a willingness to consider that asking such questions might lead us into political ideas that appear, in the sense described by Goodman, "utopian".ii

Developing the ability to imagine, discuss and defend - or object to - different political ideas demands that we encourage children to understand political questions as fundamental questions about how to live together in society, to see our current political structures as essentially malleable, and to engage with the intertwining of moral values and ideas about how to organize society. What this requires, I suggest, is a kind of "politics of imagination" (Bottici and Challand, 2011); an appreciation of the critical role of the imagination in political thought and action.

This conception of politics, which is prior to "the bifurcation between the two classically opposed ways of understanding the task of philosophically reflecting on politics - namely the 'normative' and the 'realistic'" (Ferrara, p. 40) has been articulated by Alessandro Ferrara, as follows:

Only a human form of association to which unlimited resources were available and which could equally satisfy all the ends striven after by all of its members could dispense with politics. The important role of the imagination becomes manifest here: by enabling us to project an image of the world, the imagination allows us to perceive certain ends as deserving more or less priority over others. (ibid, p. 40). 
Ferrara insists that "we should be wary of equating politics with the 'institutional' and the staatlich", as many dictionary definitions of politics do. "For politics is also the locus where new values and new needs are articulated.[...]. Politics at its best is the articulation of reasons that move the imagination". (ibid, p. 42).

I have argued that, to respond to Ecclestone's plea for "a political and educational challenge to a social project that hopes to engineer emotional and psychological well-being and character whilst avoiding civic engagement in the political questions this raises", we need to bring the political back into the classroom, and to do so in a way that offers real hope of radical social change. This involves, I suggest, engaging children in an imaginative, intellectually challenging encounter with political ideas, and helping them to understand the historical and social context of collective endeavours to translate these ideas into reality.

\section{References}

Althof, W. and Berkowitz, M. (2006) "Moral education and character education: their relationship and roles in citizenship education", Journal of Moral Education, $35: 4$, pp. 495-518.

Arthur, J. (Ed.) (2010) Citizens of Character; New Directions in Character and Value, Exeter; Imprint Academic.

Arthur, J. (2005) "The re-emergence of character education in British education policy", British Journal of Educational Studies, 53:3, pp.239-254

Arthur, J. (2003) Education with Character; The Moral Economy of Schooling, London; Routledge.

Bottici, C. and Challand, B. (2012) The Politics of Imagination, Abingdon; Birkbeck Law Press.

Callan, E. (1998) “Review of Patricia White, 'Civic Virtues and Public Schooling: Educating Citizens for a Democratic Society'”, Studies in Philosophy and Education 17:2-3, pp. 211-215.

Boyd, D. (2011) "Character education from the left field", in in DeVitis, J. and Yu, T. (Eds) Character and Moral Education; A Reader, New York; Peter Lang. 
Covaleskie, J. F. (2011) "Moralty, virtue and the democratic life", in DeVitis, J. and Yu, T. (Eds) Character and Moral Education; A Reader, New York; Peter Lang.

Crick, B. and Porter, A. (eds) (1978) Political Education and Political Literacy, London: Longman.

Crick, B. (1998) Advisory Group on Education for Citizenship and the Teaching of Democracy in Schools Qualifications and Curriculum Authority (QCA), Education for citizenship and the teaching of democracy in schools. Final report, 22 September 1998.

Ecclestone, K. and Lewis, L. (2014) “Interventions for resilience in educational settings: challenging policy discourses of risk and vulnerability", Journal of Education Policy, 29: 2.

Ecclestone, K. (2012) "From emotional and psychological well-being to character education: challenging policy discourses of behavioural science and 'vulnerability'", Research Papers in Education, 27: 4.

Ferrara, A. (2012) "Politics at its best; reasons that move the imagination", in Bottici and Challand (Eds).

Goodman, P. (1952) Utopian Essays and Proposals, New York; Random House.

Grace, G. (2003) Foreward, in Arthur, J. Education with Character; The Moral Economy of Schooling, London; Routledge.

The Independent, "Political education classes 'should be compulsory'", Saturday 23 April 2011.

Jones, H. (2013) "To boost activism beyond Red Nose Day, we need political education in schools", The Independent, 15 th March, 2013.

Kristjánsson, K. (2013) "Ten myths about character, virtue and virtue education - plus three well-founded misgivings", British Journal of Educational Studies, 61:3, pp. 269-287. 
Kymlicka, W. (2001) Politics in the Vernacular: Nationalism, Multiculturalism, and

Citizenship, Oxford; Oxford University Press.

Larmore, C. (2013) “What is political philosophy?” Journal of Moral Philosophy, 10:3, pp.

276-306.

McAdam (1999) Political Process and the Development of the Black Insurgency, 1930-1970,

Chicago; University of Chicago Press.

Mendus, Susan (2006) "Saving one's soul or founding a state: Morality and politics", Philosophia, 34:3, pp. 233-241.

Miltrany, D. (1975) The Functional Theory of Politics, London: Martin Robertson.

Morris, A. (1984) The Origins of the Civil Rights Movement: Black Communities Organizing for Change, New York: Free Press.

Rorty, R. (1999) Philosophy and Social Hope, London; Penguin.

White, P. (1983) Beyond Domination, London; Routledge and Kegan Paul.

White, P. (1980) "Political education and moral education or bringing up children to be decent members of society", Journal of Moral Education, 9:3.

Williams, B. (2008) In the Beginning Was the Deed: Realism and Moralism in Political Argument, Princeton: Princeton University Press.

Wringe, C. (1984) Democracy, Schooling and Political Education, Abingdon; Routledge.

\footnotetext{
'In adopting this phrase of Larmore's, I do not want to imply (and neither, I believe, does Larmore himself) that there is an unproblematic sense in which "people like us" can be used in a way that does not exclude others who are "not like us". Rather, I suggest that this idea can be used to open up discussion about what can be considered as basic human needs, which in turn should form the basis for any political system designed to ensure that these needs are met. I would like to thank Sharon Todd for alerting me to this point.
} 


\footnotetext{
i" I leave aside the disturbing question of why "The Knightly Virtues" are considered educationally and morally valuable or appropriate in $21^{\text {st }}$ Century Britain, and why Rosa Parks' story is included as a supplement to the "great stories of knights and heroes" that form the core of this educational programme.

iii Of course, one may disagree with the radical suggestions implied here, and may be of the view that the democratic, liberal state is the best and most defensible political system available, and that the primary educational task is to strengthen its institutions and values. This seems, indeed, to be the position behind many of the character education projects described here. Yet if it is, it needs to be explicitly articulated and defended. It is the absence of any such defence that reflects the "state fixation" mentioned above. I would like to thank Hanan Alexander for drawing my attention to the importance of this point, the broader implications of which I cannot pursue in full here.
} 